\title{
The schools' ranking in the opinion of directors of Secondary Education schools in Portugal
}

\author{
Susana Sá ${ }^{1}$ (0000-0003-1339-5745) and Palmira Alves ${ }^{2}$ \\ ${ }^{1}$ Escola Secundária Carlos Amarante, Researcher at the Research Centre of Child Studies of University of Minho (CIEC), \\ Portugal. susanaemiliasa@gmail.com; \\ ${ }^{2}$ Department of Curricular Development of the Education Institute of University of Minho, Researcher at the Research \\ Centre of Child Studies of University of Minho (CIEC), Portugal. palves@ie.uminho.pt;
}

\begin{abstract}
In order to study the schools' ranking we have to perceive in a micro towards a meso structure, in Secondary Education, what the factors that can influence the performance of schools are. In this study, we will focus on the opinion of school directors. We conducted three interviews, with two directors from two grouped schools and one from a non-grouped school, in the Northern of Portugal. The semi-structured interviews were audio recorded and later transcribed. The content was analyzed and treated with the support of the webQDA qualitative analysis software. This external evaluation affects teachers and directors, when scores are used to determine the "social" position of the school, granting them recognition or additional funds, or threatening with loss of "social register", when the score is low and, consequently, affects students, in what concerns their promotion, monitoring and graduation.
\end{abstract}

Keywords: Rankings, Secondary Education, External Evaluation, Content Analysis, webQDA

\section{Introduction}

The publication in Portugal, for the first time in 2001, of the ordered list of secondary education schools, having as basis the results of the $12^{\text {th }}$ grade national exams marks, has initiated a controversy known as "schools' rankings". Regardless of the appropriateness of the designation, it is important to know the contours that it assumes and the contexts in which it arises.

Referring to a chronological period that does not go beyond the mid-1990s, Afonso (1998) suggests that there was a "late connection" to the neoliberal ideology in Portugal. However, in a later study, the author addresses the controversial issue of schools' rankings (Afonso, 2002). Considering our argument, the question arises: what do policy makers intend with the introduction of schools' rankings?

In addition to the obvious attraction that any ranking exercises with the entities that are better classified, it is verified that few are indifferent to the presentation of a clear order, supposedly based on facts (the classifications of exams) and apparently bare of subjectivity and ambiguity. In addition, the history of the process includes refusals to make the raw data available (the classifications of exams) on the part of successive Ministries of Education, which have increased the affective adhesion to the first concrete exercise of the use of this data and, later, the following data.

Rowe $(2000$, p.76) is one of those who advise careful handling of information: if it is not valid, it leads to erroneous conclusions, with the potential risk of personal and institutional losses. The simplistic and reductive processes of interpretation can never be a good way of perceiving complex institutions such as educational institutions. Without intending to exhaust the subject, many of the rankings do not allow, namely, to know (Matos, Lopes, Nunes \& Venâncio, 2006, p. 4):

"Which factors make some schools achieve their goals better than others?; What to do to make a school improve?; What "school effect" will be directly related to the success of the teaching-learning process?; Can the school enhance the "school effect" in the sense of real improvement of effectiveness, taking into account that each student is a reflection of innumerable interactions, 
throughout their school career?; Naturally, all this is a long way from the mere ordering of schools by global averages of exam scores, an exercise that is not intended to address any of these questions."

Our purpose here is quite different from what we have seen in discussions related to this topic. Benefitting from the availability of 15 years of data, and the possibility of comparing the respective rankings, our exercise of data analysis sought to ascertain, afterwards, to what extent the implicit hypothesis in the enthusiastic use of rankings is reasonable. In other words, are rankings a reliable indicator of the quality, or effectiveness, of schools?

\subsection{On a meso scale - the Ranking}

At the moment, the school is being attacked by many: parents, guardians, researchers, journalists, students, Ministry of Education and Science, which question whether the school is fair, effective and question accusingly both its function and its mission, through the compared results, that is, the rankings.

In general, in Portugal, the Ranking of public or private education institutions is calculated only by the average obtained in some examinations of secondary education.

The newspaper, "Público", orders the Catholic University, annually, the Ranking of the institutions of public or private education, which is based on the Mathieu effect (Crahay, 2000), which is calculated as follows: on the one of the secondary education, the eight exams with the highest number of enrolled students are counted, three of the twelfth year (Portuguese, Mathematics A and History A), and five of the eleventh year (Biology and Geology, Physics and Chemistry A, Geography A, Phisolophy and Mathematics Applied to the Social Sciences). Only the exams taken on the first phase by students who attended school all year round are counted. In the "Tests" indicator, we know how many exams were taken in each school. The average indicates the average result obtained by the school and it is even possible to know the result of the previous year. The Ranking shows us in what position the school was. In the 2016 school year, ordination is done only with the schools where 50 or more exams were held. Since 2012, the rankings of the newspaper, "Público", which are conducted by the Catholic University, include socio-economic data that avoids the downsizing effect that many criticize in these tables. In 2016, the Catholic University, partner of the newspaper, "Público", selected the following factors for the organization of these rankings: the percentage of students without School Social Welfare, that is, less underprivileged, and the average of the qualifications of the parents (average number of years of schooling of the mother and father of the student). With this data, a variable was created that allows to characterize the context of each grouping or isolated school. On the website of the newspaper, "Público", this classification is done using numbers, from the least privileged context (marked as 1), to the most privileged (marked as 3 ), for example in Picture 1 (Jornal Público, 2016): 


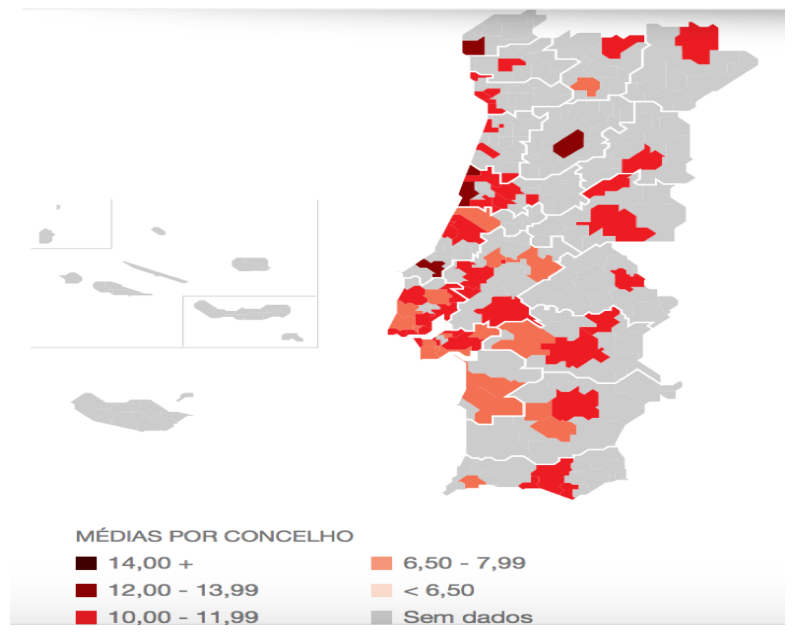

Picture 1. Example of the Rankings results for the country in a more underprivileged context

It should be noted, first, that there is a time lag: the results of the exams are from the 2015/2016 school year and the socioeconomic data is from the previous school year (2014/2015). And, secondly, the data is provided by a school grouping rather than by a school. Because a grouping typically includes multiple schools, these figures may not represent the exact universe of each school.

Due to the pressure of the ranking, schools place their educational projects as central and strategic objectives: to improve the students' achievement, reflected on the transition rates and the conclusion of the year or cycle; to compare, in the analysis of the evaluation results, the performance in the final exams and national exams with the results of the elements of internal summative evaluation (cognitive domain); to hold students responsible for their formative options, committing them to the results achieved (consulted the Educational Projects of the three grouped or nongrouped schools).

\subsection{On a micro scale - Accountability}

We know that teachers and institutions, , first and foremost, try to avoid enhancing the inequalities of natural or social origin that are, infallibly, observed among the students, demanding supplements of attention/ care in favour of those who experienced greater learning difficulties. Obviously, it is not in question that the delay in the pace of the progression of some students is a consequence of the implementation of curricular equity.

We are aware that no teaching-learning method can guarantee strict equality among students. Certainly, substantial learning can be generated in most students, and thus obtain quality performance from all students, but it can never be prevented that some transform the remaining differences into a hierarchy of values.

On a meso-scale analysis, external evaluation presupposes the concept of a common quality standard for all, which assumes that all students benefit from the same teaching or, more precisely, that they are exposed to the same curriculum. For national examinations, everyone must have had opportunities to build the competences defined by the program, even when it is argued that it is unrealistic to expect everyone to have reached the same level. Are the students offered the same opportunities to learn what will be evaluated, regardless of the school they attend?

Here a pertinent dilemma also arises. Should we privilege the autonomy of teachers or, on the contrary, reduce teachers' freedom to ensure equivalence of curricula and promote educational equity? 
If we turn to the external evaluation devices for regulatory purposes (Alves, 2004), this dilemma is decontextualized and unfounded.

In this context, the spirit that presides over formative evaluation (Abretch, 1994; Fernandes, 2006) proceeds from the "right" to make mistakes and, therefore, assumes that the results in the tests that punctuate the course of learning do not intervene in the grades or in the final classification.

In a system where automatic promotion is adopted, the calculation of the general average or the percentage and, more generally, the attribution of a grade, make no sense.

Some authors (Hanusked \& Raymond, 2005; Reeves, 2004; Darling-Hammond, 2004; Newmann, King \& Rigdon, 1997) argue that any attempt to standardize learning and teaching should be primarily used to give information about curricular changes that will strengthen the teaching-learning bonds and, consequently, schools. They understand that if there are problems, they will be an opportunity for the teacher, the school and the learning system, as it forces them to reflect on the most effective practice combined with more equal and better targeted distribution of resources. Others (Cullen \& Reback, 2006; Clotfelter, Ladd, Vigdor \& Diaz, 2004) argue that the results of the external evaluations can motivate change only if they are used to apply sanctions to those who cannot find them.

Some of the decisions justified by the external evaluation affect students, such as promotion, monitoring and graduation based on test results. Others affect teachers and directors when scores are used to determine the "social" position of the school, granting them recognition or additional funds, when they are placed on intervention regime, or threatening with loss of "social register", when the score is low.

Many questions arise from this political strategy. Will investments in better education, curriculum and schooling evolve to new standards? Or is it that standards and tests built on a foundation of inequality continued simply to certify more clearly school failure and reduce access to higher education and future employment? What is the most correct way of reading the rankings? Should it be from the inside towards the external environment of the school or from the external environment of the school into the curricular practices of the educational institution? Here is the challenge.

\section{Methodological options}

Having as research object three different school contexts, we opted for a methodology of analysis that revealed the specificities, both of the communities themselves and of the opinions of the respective directors of the different grouped or non-grouped schools under study. Therefore, we opted for qualitative research.

A substantial part of the time of the qualitative researcher is invested in the natural environment of the study, in contact, as close as possible, with the participants (Merriam, 1998) and assuming that "the subjectivity of the researcher and the subjects studied is part of the research process" (Flick, 2005), tends to analyze the data "in an inductive way" (Bogdan \& Biklen, 1994).

Considering the objectives that we propose to study, to understand to what extent the exams condition the teaching-learning practices and evaluation in Secondary Education, as well as to know which factors of the exams most influence the teaching-learning process, we intend to realize how the directors of the educational community read the rankings.

The problem of our investigation is reflected in the following questions: What does it mean, in the opinion of school directors, that their school is very well positioned in the rankings? And, consequently, another question arises that causes us restlessness as professionals of education: Can a school be fair and effective if it wants to have a prominent place in the national rankings? 
Considering the specificities of the objectives and the questions to be investigated, it seemed to us that the qualitative nature was the most adequate, as "qualitative methods cannot be regarded as independent from the research process and from the question to be studied" (Flick, 2005, p. 19) and Roldão $(2015,36)$ argues that "there are the instruments that derive from the nature of the questioning and problematization that in each study are equated."

Whether it is "simple or complex" (Stake, 2007: 236), the case study can be characterized, according to Yin (1986), "as an empirical investigation that: - investigates, in depth, a contemporary phenomenon within its context of real life; especially when - the boundaries between the phenomenon and its context are not clearly evident; and in which - many data sources are used" (p.18).

Considering that the case study (Yin, 2009) (a) works with technically distinct situations, in which there may be more variables of interest than information items, and with only one final result; (b) depends on multiple sources of evidence, requiring the information to converge in a triangulated way; (c) benefits from previous theoretical propositions that guide the collection and analysis of data, this method of study would be the best methodological option to adopt.

As for the analysis unit, Yin, (1986, p.30), argues that "which is the same as the definition of the "case"", being alterable, during the investigation, due to discoveries arising from the data collection. Our research has a design unified in three contexts in Secondary Education, two of them with only one analysis unit in each - grouped school - and the other - non-grouped school.

Finally, it is also important to highlight the procedures followed in order to respect ethical issues. Our interview with each of the three directors began after the written consent of each one; the first contact was made by e-mail, explaining our purpose and study objectives. With regard to the semistructured interviews with the directors, we previously contacted each one, requesting the interview, informing about our objectives and requesting authorization for audio recording.

In order to maintain the confidentiality of the contexts studied, the anonymity of all its participants, as well as the confidentiality of the declarations of the directors, we codified them. The respective instruments of collection and processing of data will now be subjected to detailed analysis.

\section{Collection and processing of data}

Considering the objectives of the study, we sought a detailed and rigorous description, in order to guarantee validation or credibility in a qualitative study (Amado, 2013). Some authors (Sá \& Costa, 2016, p.9) refer to "the need to establish some strategies". Among them we highlight, for example, the triangulation of the various sources collected, that is, look at the same phenomenon from different perspectives; we have also chosen to focus on triangulation of data - a mode that proves whether the information collected is confirmed by another (theoretical) source, and we turned to the transparency of the whole process that guarantees the reader the merit, credibility and reliability of the research (Neri de Souza, Costa; Neri de Souza, 2015, p. 151).

As a methodology we carried out, in an initial phase, the analysis of the results of each community separately. Subsequently, and whenever possible, in order to compare and triangulate the data, we carried out the comparative analysis between the results of the different communities. As data collection techniques, we preferred the observation, survey by interview and by questionnaire, complemented by the technique of social network analysis. 


\subsection{The interview}

Based on the observation data, we interviewed three directors from three schools in the north of the country, two grouped schools and one non-grouped.

To achieve our objectives, a semi-structured interview script was created, especially for the study. The script was intended to ensure adequate levels of consistency between the information collected. It is also important to mention that the script was elaborated having as main reference the Matrix of the investigation and the Questions and Objectives mentioned above. In this way, it was also sought to ensure the necessary consistency with regard to the formulation of issues considered critical and/ or fundamental, so as not to compromise the central objectives of the study.

With these interviews with the directors, we sought to obtain a number of clarifications, namely to understand the extent to which the exams condition the teaching-learning practices and evaluation in Secondary Education, as well as to know what factors of the exams influence the teaching-learning process the most.

It is intended to understand how the directors of the educational community read the rankings and, on the other hand, to understand, since the rankings do not take this into account, what characteristics (meso and micro) of the schools put them in the relative positions in the Rankings; to what extent are management bodies committed (in collusion) with this responsibility for achieving good results; what means they provide to the teaching community for the achievement of an improvement in these results.

In the same line of different authors (Esteves, 2006; Holsti, 1969; Silva \& Pinto, 2005; Quivy and Campenhoudt, 2003), the content analysis seemed the most appropriate way to proceed with the treatment of the testimonies and information collected.

Having started with a "fluctuating reading" (Bardin, 2004), in order to establish a first contact with the documents, subsequent readings were followed - given the richness and extent of the analyzed corpus. After this phase, the big categories began to emerge, in an inductive way, according to the pre-established objectives, the theoretical framework and the result of our interview. Since it was possible to replicate it by the three interviews, we found eighteen categories: students' IQ; the time of support that the students obtain; teachers expectation; the previous academic record of the students; the level of demand of the educational institution and its teachers; the socio-cultural characteristics of the students; the degree of selectivity of the educational establishment; the consistency of success or failure results of the students; anomalous situations justified by exogenous factors; the environmental characteristics of the educational establishment; management body.

With the help of webQDA software, we included the data (interviews and rankings) in the sources, followed by the encodings, where we built the tree with the dimensions and subcategories, and, finally, the questioning, where we questioned the data to answer the question(s) of the research.

\section{The analysis matrix}

We were aware of the specific characteristics of each community and of the great differences in relation to the theoretical framework. Thus, it was important to create a homogeneous analysis matrix that aimed at three objectives: (a) not miss the research questions in sight; (b) allow a triangulation and comparison between the various data corpus; (c) allow the comparison between contexts (table 1).

The matrix then created was a facilitator of these objectives and is presented as follows: 
Table 1. Internal coherence of research for the Dimension "Student Learning"

\begin{tabular}{|c|c|c|c|c|}
\hline Research question & Research objective & $\begin{array}{l}\text { Data } \\
\text { Corpus }\end{array}$ & $\begin{array}{l}\text { Types of } \\
\text { Analysis }\end{array}$ & $\begin{array}{l}\text { Observations } \\
\text { and } \\
\text { Expectations }\end{array}$ \\
\hline $\begin{array}{l}\text { What does it mean, in the } \\
\text { opinion of school directors, that } \\
\text { their school is very well } \\
\text { positioned in the rankings? } \\
\text { Can a school be fair and effective } \\
\text { if it wants to have a prominent } \\
\text { place in the national rankings? }\end{array}$ & $\begin{array}{l}\text { Understand the extent to which exams } \\
\text { condition teaching-learning practices } \\
\text { and evaluation in Secondary Education; } \\
\text { Know which factors of the exams most } \\
\text { influence the teaching-learning process; } \\
\text { Realize how the directors of the } \\
\text { educational community read the } \\
\text { rankings. }\end{array}$ & $\begin{array}{l}\text { Interviews } \\
\text { with } \\
\text { directors } \\
\text { Rankings } \\
\text { Data } \\
\text { published }\end{array}$ & $\begin{array}{l}\text { Content } \\
\text { Analysis } \\
\text { Documentary } \\
\text { Analysis }\end{array}$ & $\begin{array}{l}\text { We hope to } \\
\text { be able to } \\
\text { compare the } \\
\text { data from the } \\
\text { interviews } \\
\text { with the } \\
\text { directors and } \\
\text { correlate } \\
\text { them with the } \\
\text { data of the } \\
\text { published } \\
\text { rankings. }\end{array}$ \\
\hline
\end{tabular}

\section{Presentation and Discussion of Results}

The data obtained from the triangulation between the content of the three interviews and the theoretical data of the published Rankings are presented and discussed. With the help of the webQDA software, we included the data (interviews and Rankings) in the sources, followed by the encodings, where we built the tree with the dimensions and categories and, finally, questioned the data to answer the question(s) of the research, elaborating the respective matrices.

The homogeneity of the categorization results from the homogeneity of the document source, since the interviews are oral testimonies, resulting from the personal interpretation of the interviewees about the object in question, so the categorization resulted mainly from data emerging from the interview transcription, while the Rankings are published empirical data. The analysis of this variety of data sources was organized and systematized through a category tree, allowing the researcher to record the entire research context, question the data and classify relationships (Souza, Costa \& Souza, 2015). Thus, in order to organize and clarify the presentation of the results and demonstrate the internal coherence of the research, we analyze the interviews and the Rankings by research objectives, followed by discussion and a synthesis to gather ideas and highlight the results essential to this investigation, attempting to answer the questions of the research, as shown in table 2.

Table 2. Categories e Indicators of the Micro e Meso dimensions

\begin{tabular}{|c|c|l|}
\hline Dimensions & CATEGORIES & \multicolumn{1}{c|}{ Indicators } \\
\hline MICRO & Students' IQ & $\begin{array}{l}\text { A modest grading given to some students may represent an extraordinary } \\
\text { effort rate and progress on their part and/or successful commitment on } \\
\text { the part of their teachers. }\end{array}$ \\
\cline { 2 - 3 } & $\begin{array}{c}\text { The time of support the } \\
\text { students obtain }\end{array}$ & $\begin{array}{l}\text { The school's concern to provide its students with hours of support for the } \\
\text { examination subjects, included in the workload of students and teachers. }\end{array}$ \\
\cline { 2 - 3 } & $\begin{array}{l}\text { Teachers expectation } \\
\text { The previous academic } \\
\text { record of the students }\end{array}$ & $\begin{array}{l}\text { If teachers have a high expectation of the goals to achieve with their } \\
\text { students, they will probably reach the level of excellence more easily. }\end{array}$ \\
\cline { 2 - 3 } & $\begin{array}{l}\text { Exam scores reflect a consistent trend in students' academic achievement } \\
\text { or are no more than exceptions justified by factors that have little to do } \\
\text { with true success in teaching and learning. }\end{array}$ \\
\hline
\end{tabular}




\begin{tabular}{|c|c|c|}
\hline & $\begin{array}{l}\text { The level of demand of } \\
\text { the educational institution } \\
\text { and its teachers }\end{array}$ & $\begin{array}{l}\text { There are cases where students considered less able are dissuaded from } \\
\text { taking the exam so as not to harm the image of success of the educational } \\
\text { establishment. Naturally, such manipulative practice can significantly } \\
\text { affect equity among educational institutions. }\end{array}$ \\
\hline \multirow[t]{13}{*}{ MESO } & $\begin{array}{l}\text { The socio-cultural } \\
\text { characteristics of the } \\
\text { students }\end{array}$ & $\begin{array}{l}\text { The socio-cultural level of students may influence how they are } \\
\text { predisposed to learning. }\end{array}$ \\
\hline & $\begin{array}{l}\text { The degree of selectivity } \\
\text { of the educational } \\
\text { establishment }\end{array}$ & $\begin{array}{l}\text { Filtering the admissions will be reflected both in performance and in the } \\
\text { results. It should not be neglected that, in an educational market } \\
\text { scenario, the parents' freedom of choice of school is correlated with the } \\
\text { same freedom of choice of the school regarding the admission of } \\
\text { students. }\end{array}$ \\
\hline & $\begin{array}{l}\text { The consistency of } \\
\text { success or failure results of } \\
\text { the students }\end{array}$ & $\begin{array}{l}\text { The results of a year may reveal a trend of success, failure or stagnation. } \\
\text { Naturally, the change in the assumptions and the methodologies of } \\
\text { elaboration of the rankings, from one year to the next, does not allow } \\
\text { analysis. }\end{array}$ \\
\hline & $\begin{array}{l}\text { Anomalous situations } \\
\text { justified by exogenous } \\
\text { factors to the school }\end{array}$ & $\begin{array}{l}\text { Intrinsic factors (student nervousness, stress, etc.) or extrinsic (degree of } \\
\text { difficulty of the external evaluation, noise, etc.), influence the results of } \\
\text { the exams. }\end{array}$ \\
\hline & $\begin{array}{l}\text { The environmental } \\
\text { characteristics of the } \\
\text { educational establishment }\end{array}$ & $\begin{array}{l}\text { The management body and the teachers have high expectations and } \\
\text { encourage their students to achieve them. }\end{array}$ \\
\hline & Management body & $\begin{array}{l}\text { The Leadership of a democratic school that supports its teachers } \\
\text { provides, from the outset, greater freedom, well-being and a good } \\
\text { environment among the teachers to achieve fruitful work in the teaching- } \\
\text { learning process. }\end{array}$ \\
\hline & $\begin{array}{l}\text { The differences between } \\
\text { the population of each city }\end{array}$ & $\begin{array}{l}\text { Regarding purchasing power or academic qualifications. It is evident that } \\
\text { the fact that two or more schools are located in the same municipality } \\
\text { does not mean that the respective student populations are characterized } \\
\text { by similar socio-economic indicators. }\end{array}$ \\
\hline & $\begin{array}{l}\text { The numbers of students } \\
\text { of the educational } \\
\text { establishment }\end{array}$ & $\begin{array}{l}\text { Statistical significance is naturally affected by this factor. The more } \\
\text { students are tested, the greater the significance and reliability of the } \\
\text { results. }\end{array}$ \\
\hline & $\begin{array}{l}\text { The relative percentage } \\
\text { of internal, external and } \\
\text { self-proposed students }\end{array}$ & $\begin{array}{l}\text { The degree of "responsibility", "characteristics" or "goals" regarding the } \\
\text { success/failure of these different types of students is not the same. }\end{array}$ \\
\hline & $\begin{array}{l}\text { The existence and the } \\
\text { relative percentage of } \\
\text { students in technological } \\
\text { courses }\end{array}$ & $\begin{array}{l}\text { Students who attend technological courses (predominantly oriented to } \\
\text { the labor market) in each educational establishment and that are } \\
\text { proposed for examination. }\end{array}$ \\
\hline & $\begin{array}{l}\text { The quality of operation } \\
\text { of the management body }\end{array}$ & $\begin{array}{l}\text { It depends on the scientific and pedagogical organization of the school } \\
\text { teachers (the teachers have to feel involved in the process). }\end{array}$ \\
\hline & $\begin{array}{l}\text { Scientific and } \\
\text { pedagogical organization of } \\
\text { schools }\end{array}$ & $\begin{array}{l}\text { In order to have work between peers with the common goal of success } \\
\text { and improvement of the quality of learning of students. }\end{array}$ \\
\hline & $\begin{array}{l}\text { The mobility rate of the } \\
\text { teaching staff }\end{array}$ & $\begin{array}{l}\text { If the teaching staff is stable, it translates into a greater sequential } \\
\text { balance in the monitoring of their students, from the different school } \\
\text { years to the year of examination. }\end{array}$ \\
\hline
\end{tabular}

Throughout the discussion of results, we will use the term reference unit as registration units, which can be the phrase or set of words that make sense and have meaning.

In order to accomplish what we proposed, we present, in table 3, the matrix resulting from the reference units of the various indicators in the triangulation of the interviews and the rankings concerning the dimensions, meso and micro. 
Table 3. Matrix resulting from the questioning between the dimensions and the categories

\begin{tabular}{|c|c|c|}
\hline Dimensions & CATEGORIES & Reference units \\
\hline MESO & $\begin{array}{c}\text { The socio-cultural characteristics of the } \\
\text { students }\end{array}$ & 7 \\
\hline MICRO & $---------------------~$ & 0 \\
\hline
\end{tabular}

We obtained 7 reference units only for the category "The socio-cultural characteristics of the students", that is to say, only this category was the one mentioned both in the dialogue with the directors, example "... we have students from very different socio-economic backgrounds", and in the rankings documents. This makes us think about the validity of rankings for the social projection that is given to schools. This external evaluation affects teachers and directors, when scores are used to determine the "social" position of the school, granting them recognition or additional funds, or threatening with loss of "social register", when the score is low and, consequently, affects students in the sense of their promotion, monitoring and graduation.

In contrast, directors, without distinction of a grouped or non-grouped school, value other dimensions at both meso and micro scale, as we can see in table 4, which presents a questioning matrix between the interviews with the three teachers.

Table 4. Matrix resulting from the questioning between the dimensions and the categories of the interviews

\begin{tabular}{|c|c|c|}
\hline Dimensions & CATEGORIES & $\begin{array}{l}\text { Reference } \\
\text { units }\end{array}$ \\
\hline \multirow[t]{5}{*}{ MICRO } & Students' IQ & 4 \\
\hline & The time of support the students obtain & 6 \\
\hline & Teachers expectation & 7 \\
\hline & The previous academic record of the students & 7 \\
\hline & The level of demand of the educational institution and its teachers & 3 \\
\hline \multirow[t]{13}{*}{ MESO } & The socio-cultural characteristics of the students & 5 \\
\hline & The degree of selectivity of the educational establishment & 5 \\
\hline & The consistency of success or failure results of the students & 6 \\
\hline & Anomalous situations justified by exogenous factors to the school & 5 \\
\hline & The environmental characteristics of the educational establishment & 4 \\
\hline & The Management body & 5 \\
\hline & The differences between the population of each city & 6 \\
\hline & The numbers of students of the educational establishment & 6 \\
\hline & The relative percentage of internal, external and self-proposed students & 7 \\
\hline & The existence and the relative percentage of students in technological courses & 6 \\
\hline & The quality of operation of the management body & 5 \\
\hline & Scientific and pedagogical organization of schools & 5 \\
\hline & The mobility rate of the teaching staff & 5 \\
\hline
\end{tabular}

On the other hand, if directors account for so many other factors, it means that simplistic and reductive processes of interpretation can never be a good way of perceiving the value of complex institutions such as educational establishments. There are several factors that can influence the performance of schools, some of which may be subject to control at an organizational level, while others completely escape from the action or influence of schools.

As mentioned, this means that the school is questioned by everyone: parents, guardians, researchers, journalists, students, Ministry of Education and Science. They have the audacity to question whether the school is fair, whether it is effective, and accusingly question both their function and their mission, through comparative results, that is, rankings. 
As we can see in the results of table 4, directors are unanimous in referring to questions that go beyond the show-off of the final results of the external evaluation, such as the Micro dimension categories and even the Macro dimension.

In a more careful reading, we know that teachers and institutions, in the first instance, try to avoid the natural or social inequalities that are inevitably observed among students, demanding attention/care supplements for those who experience greater learning difficulties (for example, the existence of time quotas for support classes). It is not in question that the delay in the pace of student's progression is a consequence of the implementation of curricular equity.

Directors are worried about the pressure of the ranking, since in their schools it is mirrored in their educational projects as central and strategic objectives: to improve students' school success, reflected on the transition and completion rates of the year or cycle; to compare, in the analysis of the evaluation results, the performance in the final exams and national exams with the results of the elements of internal summative evaluation (cognitive domain); to hold students responsible for their formative options, committing them to the results achieved. But this is redundant with respect to the educational process and, particularly, to the teaching-learning process.

Directors also expressed apprehension in the question: if the guardians can choose the school where to entrust the education/ teaching of their students, why can't the school have the right to choose its students based on the same principle? Indeed, according to one Director, "... it is not possible to make omolettes without breaking eggs", but, according to another: "... we want our eggs to go from $M$ class to $2 X L$, in here, not caring if our size $2 X L$ is equal to the $2 X L$ of the school next door," concluding another, "we are not calibrating individuals, we are teaching and educating, that is our true function."

\section{Conclusions}

In the opinion of directors, the positioning of their school in the rankings only translates an external evaluation that unfairly affects both institution and teachers, either positively or negatively, in the sense that the scores are used to determine the "social" position of the school, granting them recognition or additional funds, if the score is high, or threatening with loss of "social register", when the score is low and, as a consequence, affects the students in their promotion, monitoring and graduation.

They consider that this translates an extremely reductive social vision for the totality of an honest, cohesive work, in which management bodies and teachers work together for a result: to raise the level of in-school success of their students to the level of demand, working hard and fruitfully in pairs, regardless of the level and type of education.

As to the second question, which has worried us so, whether a school can be fair and effective if it wants to have a prominent place in the national rankings, with these results, we have not been able to give a concise and reliable answer.

Therefore, on a micro-scale, is the purpose of the school system to develop skills, by creating opportunities, offered to students, in the fields of knowledge, of skills to use knowledge and to collaborate with peers in problem solving, as well as the experiences of personal formation structured around the individual freedom and the capacity to ethically self-determine their action, can be carried out in the professional field or be extended to the whole of citizenship, organized and applied with equal opportunities?

According to most studies in the field, the organization of schools' rankings is not enough to clarify this, because, constituting an ordering of results according to certain criteria, it does not allow to 
infer validly about elements of the school responsibility processes (Alves \& Tomé, 2006; Matos, Lopes, Nunes \& Venâncio., 2006; Cullen \& Reback, 2006; Clotfelter, Ladd, Vigdor \& Diaz, 2004).

\section{References}

Afonso, A (1998) Políticas Educativas e Avaliação Educacional. Braga: Universidade do Minho.

Afonso, A (2002) Políticas Educativas e Avaliação das Escolas: por uma prática avaliativa menos regulatória. In J. Adelino Costa; A. Neto-Mendes e A. Ventura (Orgs.). Avaliação de Organizações Educativas (pp. 31-37). Aveiro: Universidade de Aveiro.

Alves, M \& Tomé, I (2006) Os rankings das escolas secundárias em Portugal: da(s) internacionalidade(s) política(s) à sua representação nos professores. Revista Portuguesa de Pedagogia, 40-3, 237-252.

Amado, J (2013) Manual de Investigação Qualitativa em Educação. Coimbra: Imprensa da Universidade de Coimbra.

Bardin, L (2004) Análise de Conteúdo. Lisboa: Edições 70.

Bogdan, R \& Biklen, S (1994) Investigação Qualitativa em Educação. Uma introdução à teoria e aos métodos. Porto: Porto Editora.

Clotfelter, C, Ladd, H, Vigdor, J, \& Diaz, R (2004) Do school accountability systems make it more difficult for lowperforming schools to attract and retain high-quality teachers?. Journal of Policy Analysis and Management, 23(2), 251-271.

Crahay, M (2000) L'école peut-elle être juste et efficace? De l'égalité des chances à l'égalité des acquis. Pédagogies en Développement, Bruxelles.

Cullen, J, \& Reback, R (2006) Tinkering toward accolades: School gaming under a performance accountability system (No. w12286). National Bureau of Economic Research.

Darling-Hammond, L (2004) Standards, accountability, and school reform. Teachers College Record, 106(6), 1047-1085.

Esteves, M (2006) Análise de Conteúdo. In Lima, J A \& Pacheco, J A, (Orgs.). Fazer Investigação - Contributos para a elaboração de dissertações e teses. Porto: Porto Editora.

Flick, U (2005) Métodos Qualitativos na Investigação Científica. Lisboa: Monitor.

Hanushek, E, \& Raymond, M (2005) Does school accountability lead to improved student performance?. Journal of policy analysis and management, 24(2), 297-327.

Holsti, O (1969) Content Analysis for Social Sciences and Humanities. Reading, Addison-Wesley.

Jornal Público (2016) Ranking das Escolas. http://www.publico.pt/ranking-das-escolas-2016/listas, consulta realizada em 14.02.2017.

Matos, M, Lopes, C, Nunes, S \& Venâncio, I (2006) Reflexões sobre os rankings no secundário. Associação 
Portuguesa de Investigação Operacional, 26, 1-21.

Merriam, S (1998) Qualitative Research and Case Study Applications in Education. San Francisco: Jossey-Bass.

Newmann, F, King, M, \& Rigdon, M (1997) Accountability and school performance: Implications from restructuring schools. Harvard educational review, 67(1), 41-75.

Neri de Souza, D, Costa, A \& Neri de Souza, F (2015) Desafio e inivação do estudo de caso com apoio das tecnologias. F. Neri de Souza, D. Neri de Souza \& A. Costa (Ogs.). In Investigação Qualitativa: Inovação dilemas e desafios, vol. 2. (pp. 143-162). Oliveira de Azeméis, Aveiro: Ludomedia.

Quivy, R \& Campenhoudt, L (2003) Manual de Investigação em Ciências Sociais. Lisboa: Gradiva.

Reeves, D (2004) Accountability for learning: How teachers and school leaders can take charge (Vol. 160). VA: Alexandria, Association for Supervision and Curriculum Development.

Roldão, M (2015) Produção e uso do conhecimento: tensões e desafios na investigação educacional. F. Neri de Souza, D. Neri de Souza \& A. Costa (Ogs.). In Investigação Qualitativa: Inovação dilemas e desafios, vol. 2. (pp. 15-40). Oliveira de Azeméis, Aveiro: Ludomedia.

Rowe, J (2000) Assessment, League Tables and School Effectiveness: Consider the Issues and "Let's Get Real", Journal of Educational Enquiry, I, 1, 73-98.

Sá, S,\& Costa, A (2016) Critérios de Qualidade de um Estudo Qualitativo (Carta Editorial). Revista Eixo, 5(3), 912.

Silva, A \& Pinto, J (1986) Metodologia das Ciências Sociais. Porto: Edições Afrontamento (13a edição, Janeiro de 2005.

Souza, N, Costa, A, Souza, F (2015) Desafio e inovação do estudo de caso com apoio das tecnologias. (Vol. 2). In F de Souza, D de Souza \& A Costa (Orgs.), Investigação Qualitativa: Inovação, Dilemas e Desafios, (pp. 143-162), Oliveira de Azeméis, Aveiro: Ludomedia.

Stake, R (2007) A Arte da Investigação com Estudos de Caso. Lisboa: Fundação Calouste Gulbenkian.

Yin, R (1986) Case Study Research: Design and methods. Londres: Sage.

Yin, R (2009) Case Study Research - Design and Methods. Fourh Edition. Thousand Oaks, California: Sage Publications Inc. 